\title{
Reproductive Strategy of Labeobarbus batesii (Boulenger, 1903) (Teleostei: Cyprinidae) in the Mbô Floodplain Rivers of Cameroon
}

\author{
Claudine Tekounegning Tiogué, ${ }^{1}$ Minette Tabi Eyango Tomedi, ${ }^{2}$ and Joseph Tchoumbouée ${ }^{3}$ \\ ${ }^{1}$ The University of Dschang, Faculty of Agronomy and Agricultural Sciences, Laboratory of Applied Ichthyology and Hydrobiology, \\ P.O. Box 222, Dschang, Cameroon \\ ${ }^{2}$ The University of Douala, Institute of Fisheries and Aquatic Sciences of Yabassi, P.O.Box 2701, Douala, Cameroon \\ ${ }^{3}$ The University of Mountains, P.O. Box 208, Banganté, Cameroon
}

Correspondence should be addressed to Claudine Tekounegning Tiogué; tekou_claudine@yahoo.fr

Received 20 March 2012; Revised 12 November 2012; Accepted 6 February 2013

Academic Editor: Michael Thompson

Copyright (C) 2013 Claudine Tekounegning Tiogué et al. This is an open access article distributed under the Creative Commons Attribution License, which permits unrestricted use, distribution, and reproduction in any medium, provided the original work is properly cited.

\begin{abstract}
Aspects of the reproductive strategy of African carp, Labeobarbus batesii, were investigated from May 2008 to October 2009 in the Mbô Floodplain of Cameroon. Samples were collected monthly from artisanal fishermen. The total length and total body mass of each specimen were measured to the nearest $\mathrm{mm}$ and $0.01 \mathrm{~g}$, respectively. Sex was determined by macroscopic examination of the gonads after dissection. The sex ratio was female skewed (overall sex ratio: $1: 1.42$ ). Females reach sexual maturity at a larger size $(213 \mathrm{~mm})$ than the males $(203 \mathrm{~mm})$. The mean gonadosomatic index ranges from $0.32 \pm 0.17 \%$ to $1.91 \pm 1.15 \%$, whereas the mean $K$ factor ranges from $0.90 \pm 1.09$ to $1.10 \pm 0.13$. These two parameters are negatively correlated. The reproduction cycle begins in mid-September and ends in July of the next year, and they are reproductively quiescent for the rest of the year. Labeobarbus batesii is a group-synchronous spawner with pulses of synchronised reproduction spread over a long period. The mean absolute, potential, and relative fecundities are $2898 \pm 2837$ oocytes, $1016 \pm 963$ oocytes, and $9071 \pm 7184$ oocytes $/ \mathrm{kg}$, respectively. The fecundity is higher and positively correlated with the gonad mass than with body size. Its reproductive biology suggests that $L$. batesii is suitable for pond culture.
\end{abstract}

\section{Introduction}

In many parts in the world, cyprinid fish species are important in aquaculture, representing $61 \%$ of world production in $2008[1,2]$. Although Asia is the largest aquaculture producer of cyprinids in the world, with its endogenous species, the diversity of freshwater fishes in Africa (3200 species) is comparable to that in Asia (3000 species) [3], but Africa lacks significant cyprinid aquaculture.

In general, the problems for aquaculture in sub-Saharan Africa are related to poor breeding techniques and a limited number of suitable species [4]. Thus, despite the diversity of African fishes, the main species that are farmed are imported from outside of Africa. Of the nearly 500 species of African cyprinids [5], only Labeo parvus (Boulenger) is used for aquaculture [6-9]. The technological support that accompanies domesticated exotic species contributes to the neglect of indigenous species that would require a long process of domestication for aquaculture [3]. Moreover, the harmful impact of the introduction of exotic species is likely to divert attention from the aquaculture potential of native species [10]. Indeed, the introduction of new species is the main cause of extinction of native freshwater fishes in Africa [11]. Endogenous fish species found in several agroecological zones of Cameroon are important candidates for aquaculture.

The African carp, Labeobarbus batesii (Boulenger, 1903), is a common and widespread species of the Cyprinidae family in Lower Guinea. Elsewhere, it is known from the Dja and Tibesti in Tchad [12]. In Cameroon, the Mbô Floodplain is an important scientific and socioeconomic centre, where 
the fishery improves the incomes and the consumption rates of animal protein of the local people [13]. Labeobarbus batesii is a high nutritional value fish in the Mbô Floodplain and other Cameroonian zones. Four families of fish species (Channidae, Cichlidae, Clariidae, and Cyprinidae) are fished in this ecosystem. The reproductive biology of a few species has been studied in this zone $[13,14]$, but apart from one small study on its growth [15], nothing is known about the reproductive biology of Labeobarbus batesii, even though it is economically important. Our aim, therefore, is to describe reproductive traits of the African carp Labeobarbus batesii to assess its suitability for aquaculture in this area.

\section{Material and Methods}

2.1. Physical Environment. The study was carried out from May 2008 to October 2009 in the Mbô Floodplain (MF) (NL $5^{\circ} 10^{\prime}$, LE $\left.9^{\circ} 50^{\prime}\right)$ in Cameroon, an area of $390 \mathrm{~km}^{2}$ with an altitude of about $700 \mathrm{~m}$. It is located between the littoral and west regions of Cameroon. The soil is volcanic, sandy and favourable to agriculture all year round. MF has a hot and humid climate characterised by two seasons; the dry season starts in mid-November and ends in mid-March. The temperature ranges from $17^{\circ} \mathrm{C}$ to $30^{\circ} \mathrm{C}$ and the relative humidity varies from $49 \%$ to $98 \%$ in dry and rainy seasons, respectively. The average rain fall is about $1860 \mathrm{~mm}$. The MF Rivers descend from the Bambouto Mountains (Menoua River), which is part of the Manengouba Massif (Nkam and Black Water Rivers). Several streams, such as Metschie and Mfouri, descend from the Bana Massif (Figure 1). All are drained by the Wouri River, which flows into the Atlantic Ocean [15].

2.2. Fish Samples. Monthly samples, totalling 448 samples of Labeobarbus batesii (387 mature and 61 undetermined sexes), were obtained from artisanal fishermen from May 2008 to October 2009. Ten sampling sites were identified and were gathered into two zones (confluence and interconfluence). Fishes were collected by means of traditional fishing gear (bow nets, hooks, and gill nets). Collected fish were counted, rinsed and anesthetized in the solution of tricaine methanesulfonate (MS 222), prepared by dissolving $4 \mathrm{~g}$ of MS 222 in $5 \mathrm{~L}$ tap water, and then preserved in $10 \%$ formalin. The samples were transported to the laboratory for analysis. Fishes were identified according to the criteria of [12].

Fishes were measured for total length to the nearest $1.0 \mathrm{~mm}$. The total body mass was measured using an electronic balance (Sartorius Competence) to the nearest $0.01 \mathrm{~g}$. The morphometric characteristics recorded for each fish were used to calculate Fulton's $K$ condition factor by the formula $K=100 W * \mathrm{TL}^{-3}$, where $W$ is the total body mass and TL is the total length.

The sex of fish was determined by macroscopic examination of the gonads after dissection and the sex ratio compared to $1: 1$ using a Chi-square test $\left(\chi^{2}\right)[16]$. The length at which $50 \%\left(\mathrm{~L}_{50}\right)$ of fish matured was determined by visual estimation after plotting the percentage of mature fish against their lengths. The gonadosomatic index (GSI) was calculated by expressing the gonad mass as a percentage of body mass [17]. Spawning and breeding periodicity was determined from the inverse trend of GSI and $K$ condition factor and by an examination of the GSI monthly variation during 18 months: higher values of GSI showed the breeding season while the lowest values showed a sexual quiescence.

The oocytes were removed from gravid fish, weighed, and preserved in modified Gilson's fluid (nitric acid $17 \mathrm{~mL}$, acetic acid $4 \mathrm{~mL}$, mercuric chloride $20 \mathrm{~g}$, ethanol $95 \%$, and distilled water $900 \mathrm{~mL}$ ) [18]. The preserved ovaries were washed several times to get rid of the preservative and the oocytes were separated from ovaries in Petri dish. The potential fecundity (PF) and absolute fecundity (AF) were estimated by counting the number of mature oocytes or all oocytes, respectively, from a known weight of subsamples collected from the ovaries. These two fecundities were calculated by multiplying the total mass of oocytes by the number of oocytes per gram [19]. The relative fecundity (RF) was obtained as the number of oocytes per unit fish mass. The relationship between the absolute fecundity and the fish length was determined by power regression technique with the following equation: $\mathrm{AF}=a X^{b}$. The relationship between the absolute fecundity and the fish body mass or between the absolute fecundity and the gonad mass was determined by linear regression. The equation was $\mathrm{AF}=a+b X$, where $\mathrm{AF}=$ absolute fecundity; $X$ = fish length, fish body mass, or gonad mass; $a=$ regression constant; $b=$ regression coefficient.

\section{Results}

3.1. Relative Abundance Distribution. Fishes were only caught between July and October in the interconfluences (Table 1), but the number and the biomass were significantly higher $(P<0.01)$ than those caught at the confluences. The number of fishes caught and their biomass in the inter-confluences or in the rainy season were significantly higher $(P<0.01)$ than those in the confluences or in the dry season, respectively. Similarly, the number and biomass of fishes collected in 2008 were significantly higher $(P<0.01)$ than those in 2009 .

3.1.1. Sex Ratio. The sex ratio of fish varied from month to month (Table 2 ). The pooled sex ratio (160 males and 228 females, mean ratio of $1: 1.42)$ over all months differed significantly from the expected ratio $(P<0.05)$. Within months, males were dominant only in December 2008 (1:0.60). The expected sex-ratio $(1: 1)$ was observed in only two months (July 2008 and February 2009).

3.1.2. Sexual Maturity Size. Gravid fishes $(n=37)$ ranged from 230 to $505 \mathrm{~mm}$ in length and from 105 to $1300 \mathrm{~g}$ in mass. Males matured at $203 \mathrm{~mm}$ total length (TL) and females at $213 \mathrm{~mm}$ total length. In overall population, $\mathrm{L}_{50}$ were $200 \mathrm{~mm}$ total length (Figure 2).

3.1.3. Gonadosomatic Index, K Condition Factor, and Spawning Periods. The mean gonadosomatic indices (GSIs) ranged from $0.32 \pm 0.17 \%$ in August to $1.91 \pm 1.15 \%$ in December 2008. There was a significant $(P<0.01)$ monthly variation 


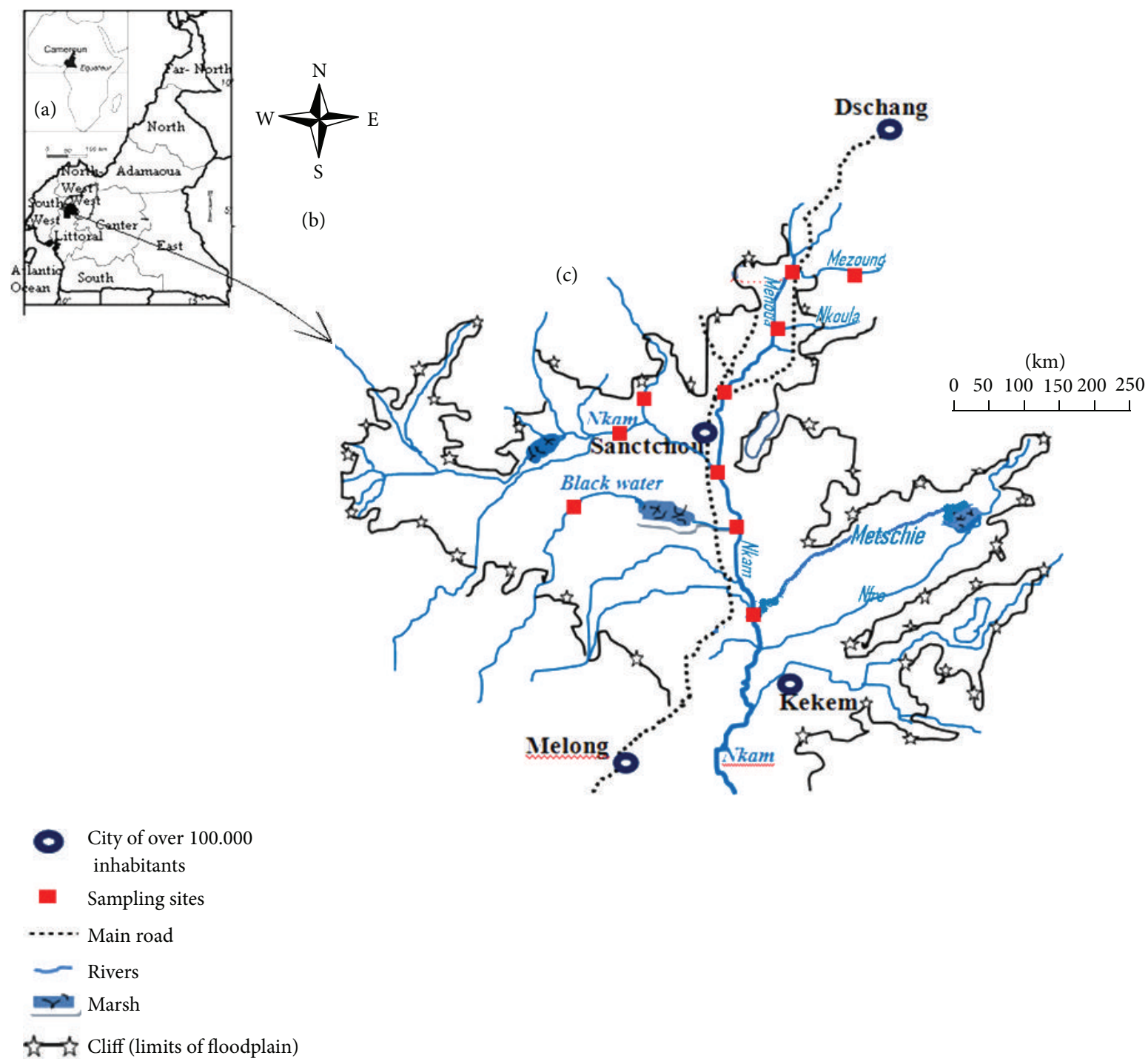

Figure 1: Study area: (a) Africa, (b) Cameroon, (c) Mbô Floodplain.

in the gonadosomatic index. Both years recorded the highest values between November 2008 and June 2009 and the lowest values from July to October. Months with high standard deviations occur when the fishes are reproductively active (Figure 3(a)). The monthly changes in mean GSIs revealed an increase in reproductive activity in both sexes in September (Figure 3(b)). The monthly mean GSIs of female Labeobarbus batesii varied from $0.36 \%$ in August 2008 to $1.94 \%$ in March 2009 and of males varied from $0.54 \%$ in October 2009 to $2.97 \%$ in February 2009 (Figure 3(a)). The mean male GSIs $(1.31 \pm 0.81 \%)$ were significantly higher $(P<0.01)$ than those of females $(0.97 \pm 0.53 \%)$. Male mean GSIs, which peaked in February, June, and November, were significantly higher $(P<$ 0.05) than in other months. Female mean GSIs peaked in March and December. Female mean GSIs were significantly lower $(P<0.01)$ in the rainy season $(0.91 \pm 0.37 \%)$ than in dry season $(1.25 \pm 0.62 \%)$. The mean GSIs of male in the dry season $(1.92 \pm 0.76 \%)$ were significantly higher $(P<0.01)$ than in the wet season $(1.01 \pm 0.65 \%)$.
The mean female GSIs were lower $(P>0.05)$ in 2009 $(0.91 \pm 0.50 \%)$ than in $2008(1.05 \pm 0.58 \%)$, whereas the mean male GSIs in $2008(1.17 \pm 0.82 \%)$ and in $2009(1.44 \pm 0.83 \%)$ were significantly different $(P<0.05)$ (Figure $3(\mathrm{~b})$ ).

The mean condition factor, $K$, ranged from $0.90 \pm 1.09$ in March 2009 to $1.10 \pm 0.13$ in September 2008 with significant differences $(P<0.05)$ between years and months. $K$ was significantly negatively correlated $(r=-0.31 ; P<0.05)$ with the gonadosomatic index (Figure 4 ).

3.1.4. Fecundity. Out of 227 females sampled, only 37 (16.30\%) were gravid with ripe oocytes for fecundity estimation. Absolute and potential fecundities varied from 484 to 14034 oocytes and from 240 to 4043 oocytes respectively. Relative fecundity varied from 1492 to 37188 oocytes $/ \mathrm{kg}$. Mean absolute and potential fecundities were significantly $(P<0.05)$ higher in 2008 than in 2009. These fecundities were not significantly different $(P>0.05)$ in the dry season 
TABLE 1: Number and mass of Labeobarbus batesii captured in each month and in each zone of the Mbô Floodplain.

\begin{tabular}{|c|c|c|c|c|c|c|c|c|c|c|c|}
\hline \multirow{2}{*}{\multicolumn{2}{|c|}{ Period }} & \multicolumn{4}{|c|}{ Zone } & \multicolumn{4}{|c|}{ Season } & \multirow{2}{*}{\multicolumn{2}{|c|}{ Overall }} \\
\hline & & \multicolumn{2}{|c|}{ Confluence } & \multicolumn{2}{|c|}{ Inter-confluence } & \multicolumn{2}{|c|}{ Rainy } & \multicolumn{2}{|c|}{ Dry } & & \\
\hline Year & Month & $n$ & Biomass $(\mathrm{g})$ & $n$ & Biomass (g) & $n$ & Biomass (g) & $n$ & Biomass (g) & $n$ & Biomass (g) \\
\hline \multirow{9}{*}{2008} & M & $13(4 i)$ & 2160 & & & $13(4 \mathrm{i})$ & 2160 & & & $13(4 i)$ & 2160 \\
\hline & $\mathrm{J}$ & $10(1 i)$ & 1543 & & & 10 (1i) & 1543 & & & 10 (li) & 1543 \\
\hline & $J$ & & & 35 & 5153 & 35 & 5153 & & & 35 (11i) & 5153 \\
\hline & A & & & $61(6 i)$ & 12430 & $61(6 i)$ & 12430 & & & $61(6 i)$ & 12430 \\
\hline & $S$ & & & $85(5 i)$ & 17577,5 & $85(5 i)$ & 17577,5 & & & $85(5 i)$ & 17577,5 \\
\hline & $\mathrm{O}$ & 16 & 4336 & & & 16 & 4336 & & & 16 & 4336 \\
\hline & $\mathrm{N}$ & 12 & 3267 & & & & & 12 & 3267 & 12 & 3267 \\
\hline & $\mathrm{D}$ & 32 & 6511 & & & & & 32 & 6511 & 32 & 6511 \\
\hline & Overall & $83(5 i)$ & $17817^{\mathrm{b}}$ & 181 (11i) & $35160,5^{\mathrm{a}}$ & $220(16 i)$ & $43199,5^{\mathrm{a}}$ & 44 & $\mathbf{9 7 7 8}^{\mathrm{b}}$ & $264(27 i)$ & $52977,5^{\mathrm{a}}$ \\
\hline \multirow{11}{*}{2009} & $\mathrm{~J}$ & $34(5 i)$ & 4786 & & & & & $34(5 i)$ & 4786 & $34(5 i)$ & 4786 \\
\hline & $\mathrm{F}$ & 2 & 380 & & & & & 2 & 380 & 2 & 380 \\
\hline & M & $9(3 \mathrm{i})$ & 2480 & & & & & $9(3 \mathrm{i})$ & 2480 & $9(3 \mathrm{i})$ & 2480 \\
\hline & A & 8 & 2365 & & & 8 & 2365 & & & 8 & 2365 \\
\hline & M & $13(1 \mathrm{i})$ & 3170 & & & $13(1 \mathrm{i})$ & 3170 & & & $13(1 \mathrm{i})$ & 3170 \\
\hline & $\mathrm{J}$ & 7 & 1215 & & & 7 & 1215 & & & 7 & 1215 \\
\hline & $\mathrm{J}$ & & & 5 & 975 & 5 & 975 & & & 5 & 975 \\
\hline & A & 10 & 1615 & 7 & 1110 & 17 & 2725 & & & 17 & 2725 \\
\hline & S & 6 & 1005 & 37 (1i) & 5080 & 43 (1i) & 6080 & & & 43 (1i) & 6080 \\
\hline & $\mathrm{O}$ & & & $46(24 i)$ & 8085 & $46(24 \mathrm{i})$ & 8085 & & & $46(24 i)$ & 8085 \\
\hline & Overall & $82(9 i)$ & $17016^{\mathrm{a}}$ & $95(25 i)$ & $15250^{\mathrm{a}}$ & $139(26 i)$ & $24620^{\mathrm{a}}$ & $45(8 i)$ & $7646^{\mathrm{b}}$ & $184(34 i)$ & $32266^{\mathrm{b}}$ \\
\hline \multicolumn{2}{|c|}{ Overall } & $172(14 i)$ & $34833^{b}$ & $276(36 i)$ & $50410,5^{\mathrm{a}}$ & $359(42 i)$ & $67819,5^{\mathrm{a}}$ & $89(8 \mathrm{i})$ & $17424^{\mathrm{b}}$ & 448 (61i) & 85243,5 \\
\hline
\end{tabular}

$\overline{\mathrm{a}, \mathrm{b}}$ Numbers with same letters in exponent are not significantly different within years, seasons, or capture zones $(P>0.05)$, (i): undetermined sex (immature or rottenness).

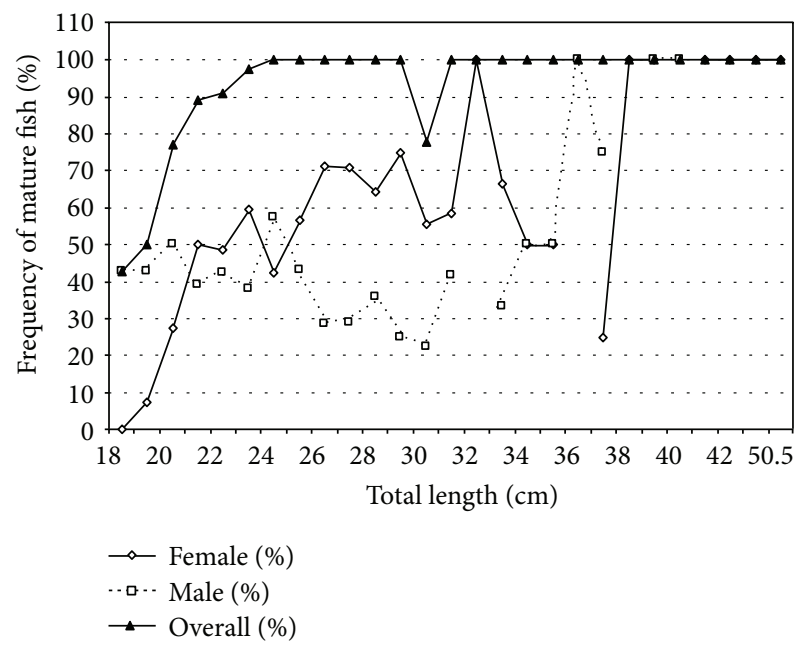

Figure 2: Percentage occurrence of mature Labeobarbus batesii at different lengths.

than the rainy season, or in the confluences than in the interconfluences. Similarly, relative fecundity was not significantly different in 2008 than in 2009, or in the dry season and in the confluences than in the rainy season and in the interconfluences (Table 3).

The number of eggs per fish all increased with total mass, gonad mass, and absolute fecundity (Figures 5(a), 5(b), and $5(c))$. The best fit relationship for total mass was a power function, whereas linear regressions were used for the other two factors. Coefficients of determination $\left(R^{2}\right)$ values were $0.36,0.43$, and 0.80 respectively for total length, total mass and gonad mass relationships.

\section{Discussion}

4.1. Relative Abundance Distribution of Labeobarbus batesii. The lack of fishes in the inter-confluence in the dry season and the beginning of the rainy season can be explained by the fact that the water level decreases and the fishes migrate to other areas of catchments or prepare for spawning. Additionally, there is reduced activity of fishing during this period.

4.2. Sex Ratio. The overall sex ratio of $1: 1.42$ in favour of females in the fishery is similar to that observed in other species: Labeo coubie $(1: 1.67)$ and Rasbora tawarensis $(1: 3.39)$ $[14,20]$. These results might signify that the reproductive 
TABLE 2: Annual and monthly variation in sex ratio (male: female) of Labeobarbus batesii.

\begin{tabular}{|c|c|c|c|c|c|c|}
\hline Year & Month & $\begin{array}{c}\text { Total } \\
\text { sample } \\
(n)\end{array}$ & $\begin{array}{c}\text { Male } \\
(n)\end{array}$ & $\begin{array}{c}\text { Female } \\
(n)\end{array}$ & Sex ratio & $\chi^{2}$ \\
\hline \multirow{9}{*}{2008} & May & 9 & 4 & 5 & $1: 1.25$ & 0.020 \\
\hline & June & 9 & 4 & 5 & $1: 1.25$ & 0.020 \\
\hline & July & 24 & 12 & 12 & $1: 1$ & \\
\hline & Aug. & 55 & 22 & 33 & $1: 1.5$ & 3.156 \\
\hline & Sept. & 80 & 38 & 42 & $1: 1.10$ & 0.006 \\
\hline & Oct. & 16 & 1 & 15 & $1: 15$ & 3.480 \\
\hline & Nov. & 12 & 3 & 9 & $1: 3$ & 0.530 \\
\hline & Dec. & 32 & 20 & 12 & $1: 0.60$ & 0.120 \\
\hline & Overall in 2008 & 237 & 104 & 133 & $1: 1.28$ & 1.75 \\
\hline \multirow{11}{*}{2009} & Jan. & 29 & 14 & 15 & $1: 1.07$ & 0.051 \\
\hline & Feb. & 2 & 1 & 1 & $1: 1$ & \\
\hline & March & 6 & 2 & 4 & $1: 2$ & 0.180 \\
\hline & April & 8 & 2 & 6 & $1: 3$ & 0.480 \\
\hline & May & 12 & 3 & 9 & $1: 3$ & 0.530 \\
\hline & June & 7 & 4 & 3 & $1: 0.75$ & 0.141 \\
\hline & July & 5 & 0 & 5 & $0: 5$ & $4.35^{*}$ \\
\hline & Aug. & 17 & 6 & 11 & $1: 1.83$ & $3.95^{*}$ \\
\hline & Sept. & 42 & 18 & 24 & $1: 1.33$ & 3.042 \\
\hline & Oct. & 22 & 6 & 16 & $1: 2.66$ & $5.46^{*}$ \\
\hline & Overall in 2009 & 150 & 56 & 95 & $1: 1.70$ & $5.02^{*}$ \\
\hline \multicolumn{2}{|c|}{ Overall in the floodplain } & 387 & 160 & 227 & $1: 1.42$ & $4.05^{*}$ \\
\hline
\end{tabular}

$n$ : number of fish, significant at ${ }^{*}=0.05$, and $\chi^{2}$ : Chi-square.

strategy of fish species should be the polygamy or an $\mathrm{r}$ selected reproductive strategy where the number of larvae is high but with less parental care [21]. The female biased sex ratio in the sample may be due to the differential fishing factors related to seasons and schooling of fishes in the feeding and spawning grounds, or to selective fishing for the large fish, rather than reflecting a real population sex ratio. Sex ratio divergence might also be explained by partial segregation of mature individuals through the preference of school formation, rendering one sex more vulnerable to capture [14]. Additionally, once fertilization of eggs is completed, males may move from spawning to feeding areas located in the shallows where they are not easily caught. In contrast to our data, males outnumber females in the cyprinid fish, Garra rufa (1.10:1) [19], and the sex ratios are equal in Labeo senegalensis [22]. The monthly variation in sex ratios might be an adaptation of reproductive strategies of tropical species to their hydrological environment [22].

4.3. Sexual Maturity Size. Females reach sexual maturity at a larger size $(213 \mathrm{~mm})$ than males $(203 \mathrm{~mm})$, which presumably allows for an increase for egg production. Thus, males may grow slower than the females or males may mature earlier than the females. Labeo senegalensis shows similar size differences at maturity $(290 \mathrm{~mm}$ and $257 \mathrm{~mm})$ in the Oueme Bassin in Benin [22] to L. batesii, whereas Labeo parvus is smaller at sexual maturity $(155 \mathrm{~mm}$ and $129 \mathrm{~mm})$ in Benin [23] than L. batesii in our study. The minimum length recorded for specimens sampled was $170 \mathrm{~mm}$, which may indicate overfishing. Hence, close and less intense fishing during October 2008-June 2009 (period of abundance of gravid L. batesii) would help the conservation of the natural stock of fishes by allowing fishes to breed at least once in their lifetime.

4.4. Gonadosomatic Index, K Condition Factor, and Spawning Periods. The cyclic monthly variation of the condition factor, $K$, is inversely correlated to GSI, indicating that $L$. batesii uses muscular or fat reserves and the viscera to fuel reproduction. Similar observations have been reported for, Barbus callensis and Barbus fritschi [24]. Multiple GSI peaks observed on February, March, June, and December characterise a fractional multiple spawning [25]. An intermittent breeding cycle has the advantages of reduced larval crowding and a decreased impact of predation and unfavourable environmental conditions on eggs and larvae [25]. Thus, according to [26], the oogenesis is the group-synchronous type, with pulses of reproduction spread over a long period. The reproductive cycle begins in mid-September 2008 and ends in July 2009, with no reproduction for the rest of the year (end-July 2009 to mid-September 2009). As multiple spawning over a protracted season has major benefits in aquaculture because it provides a consistent supply of high quality larval [25], the breeding biology of L. batesii makes it a suitable candidate for aquaculture. The status of the gonads of fishes caught during the nonreproductive period revealed that most of them were spent, but juveniles were abundant at that time.

4.5. Fecundity. A lower proportion of gravid female L. batesii (37 out of 227) was recorded in this study than for the cyprinid Labeo coubie (58 out of 205) [14], but it was higher than for Labeo parvus (41 out of 461) [23]. The absolute fecundity was low compared to other cyprinids, Barbus grypus (16000-235784 oocytes) [27], Labeo senegalensis (1294874832 oocytes) [22], and Labeo parvus (8723-124363 oocytes) [28], but was higher than for Garra rufa (283-3794 oocytes) [19]. The potential fecundity recorded for L. batesii was higher than 128 oocytes reported for the cyprinid Liza klunzingeri [29]. The mean relative fecundity was higher than the 199415920 oocytes/kg reported for Barbus holotaenia [29] but lower than Garra rufa (109430 oocytes/kg) [19] and Labeo Parvus (357000 \pm 22000 oocytes $/ \mathrm{kg}$ ) [23].

Fecundity varied within years, months, and zones, which may be due to the differences in fish sizes and food availability [30]. Fecundity is higher in the confluences than in the interconfluences, which suggests that the fishes migrate from inter-confluences to confluences for spawning, mainly during rainy season floods. The relationships between fecundity and fish sizes or gonad mass recorder for $L$. batesii are also observed for the fish species in a natural west African Lake by [30]. The positive relationships between fecundity and length $\left(R^{2}=0.36\right)$ and fecundity and body mass $\left(R^{2}=0.43\right)$ were 
TABLE 3: Female Labeobarbus batesii fecundity according to the year, season, and capture zone.

\begin{tabular}{|c|c|c|c|c|c|c|c|}
\hline \multirow{2}{*}{$\mathrm{F}$} & \multicolumn{2}{|c|}{ Year } & \multicolumn{2}{|c|}{ Season } & \multicolumn{2}{|c|}{ Zone } & \multirow{2}{*}{ Overall (37) } \\
\hline & $2008(21)$ & 2009 (16) & Dry (13) & Wet (24) & Conf. (27) & Inter. (10) & \\
\hline $\mathrm{RF}$ & $6530 \pm 4061^{\mathrm{b}}$ & $12400 \pm 9001^{\mathrm{a}}$ & $9770 \pm 5420^{\mathrm{a}}$ & $8487 \pm 5720^{\mathrm{a}}$ & $9290 \pm 4001^{\mathrm{a}}$ & $7955 \pm 7400^{\mathrm{a}}$ & $9071 \pm 7184$ \\
\hline $\mathrm{AF}$ & $4062 \pm 3708^{\mathrm{a}}$ & $2014 \pm 1635^{\mathrm{b}}$ & $2977 \pm 2623^{\mathrm{a}}$ & $2521 \pm 2376^{\mathrm{a}}$ & $2900 \pm 2760^{a}$ & $2930 \pm 2348^{\mathrm{a}}$ & $2898 \pm 2837$ \\
\hline $\mathrm{PF}$ & $1381 \pm 1211^{\mathrm{a}}$ & $739 \pm 619^{b}$ & $1108 \pm 638^{\mathrm{a}}$ & $893 \pm 328^{\mathrm{a}}$ & $954 \pm 512^{\mathrm{a}}$ & $943 \pm 418^{\mathrm{a}}$ & $1016 \pm 963$ \\
\hline
\end{tabular}

${ }^{\mathrm{a}, \mathrm{b}}$ Numbers with same letters in exponent are not significantly different within years, seasons, or capture zones $(P>0.05)$; F: fecundity, RF: relative fecundity (number of oocytes per kilogram body mass), AF: absolute fecundity (total number of oocytes per female), PF: Potential fecundity (number of mature oocytes per female), ( ): number of females, Conf.: confluence, Inter.: Inter-confluence.

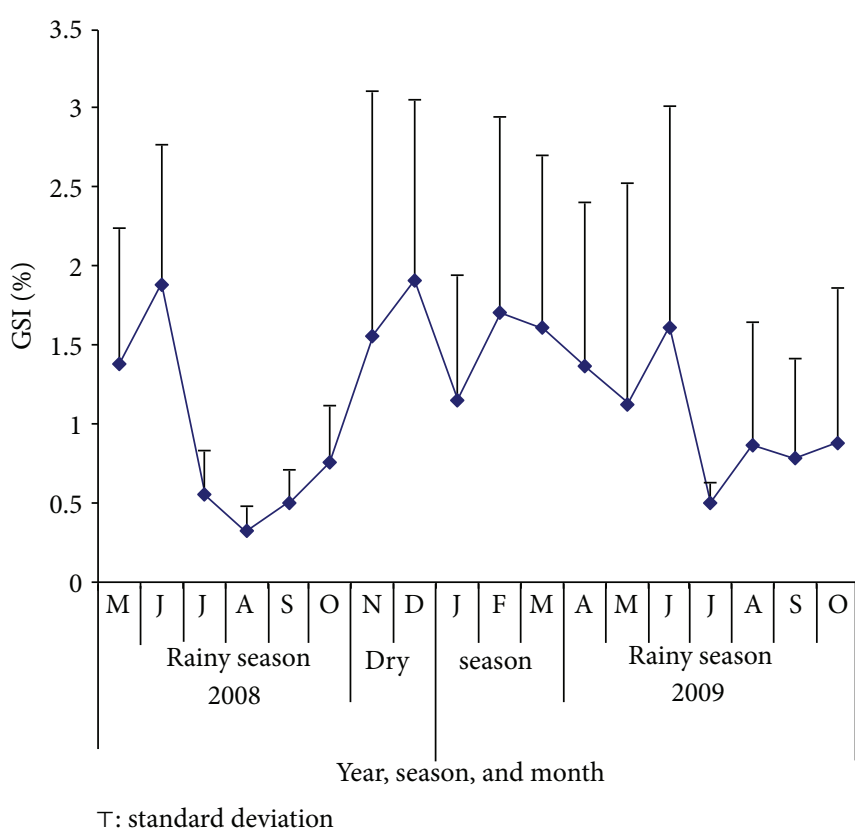

(a)

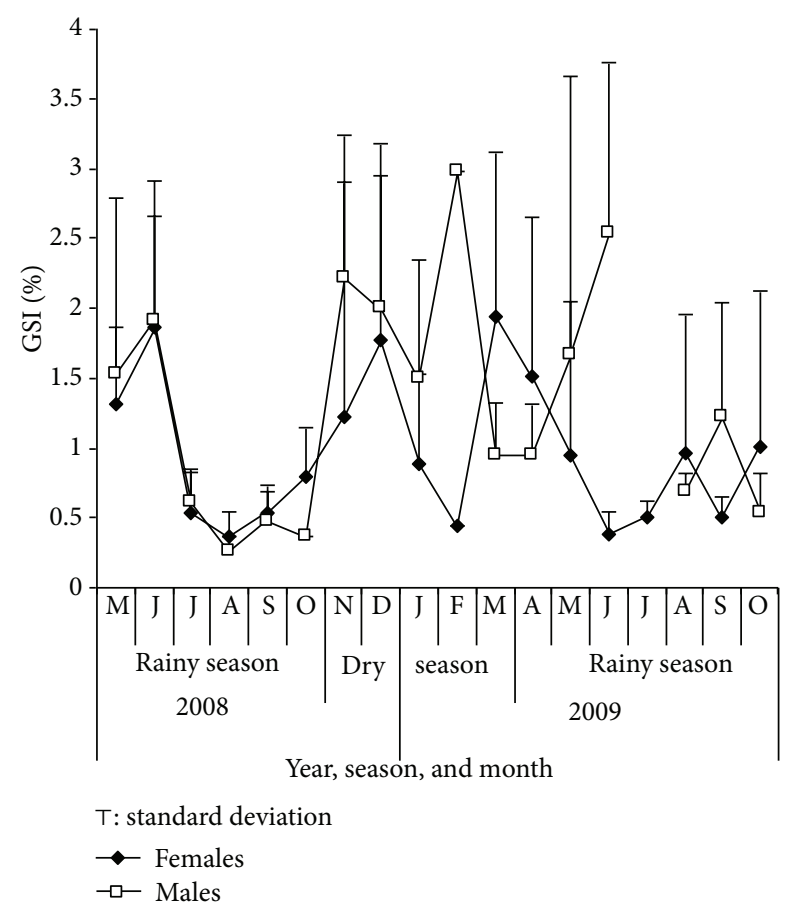

(b)

FIGURE 3: Monthly variation of mean gonadosomatic indices (GSI) for both sexes between seasons and years (a), mean gonadosomatic indices of females and males of Labeobarbus batesii (b).

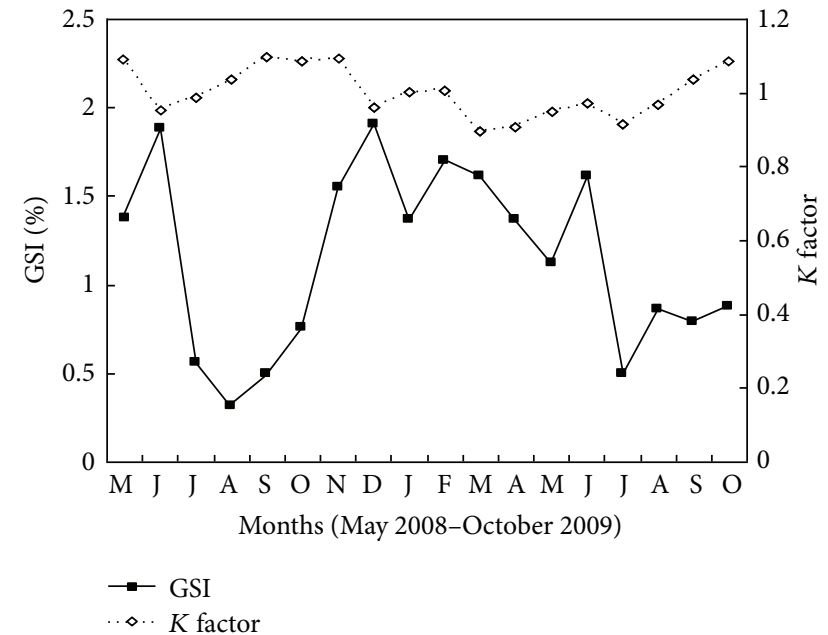

FIGURE 4: Monthly variation of mean gonadosomatic index (GSI) and condition factor $K$ for both sexes of Labeobarbus batesii. comparable to those of $R^{2}=0.48$, recorded for Labeo parvus [28]. However, these values were higher than those recorded for Labeo coubie $\left(R^{2}=0.18\right.$ and 0.10 , resp. [14]). The coefficient of determination for the relationship between fecundity and gonad mass $\left(R^{2}=0.80\right)$ for $L$. batesii is higher than the values obtained with the fish size. Thus, it is clear that the gonad weight is better correlated with reproductive capacity than fish size. Fish species with these types of relationships have rapid growth and high fertility [31], characteristics that are important for aquaculture species. Similar results were reported for other cyprinids such as Garra rufa [19], Barbus holotaenia [32], and Labeo parvus $\left(R^{2}=0.87\right)$ [23].

\section{Conclusion}

Females of Labeobarbus batesii are caught more frequently than males in the MF of Cameroon, and they reach sexual maturity at a larger size than the males. Multiple peaks of GSI 


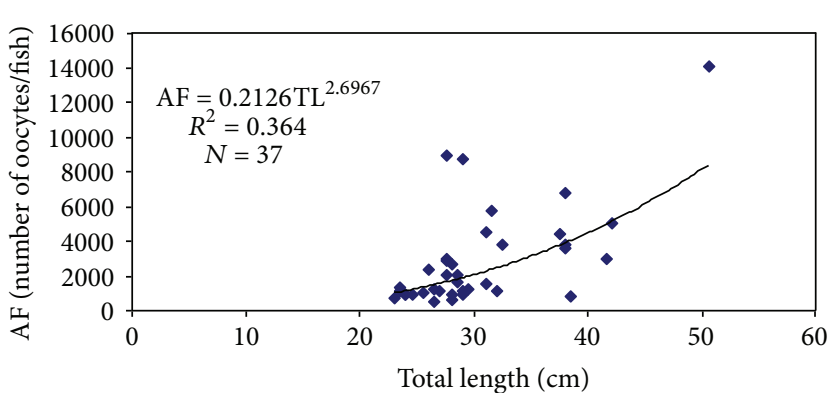

(a)

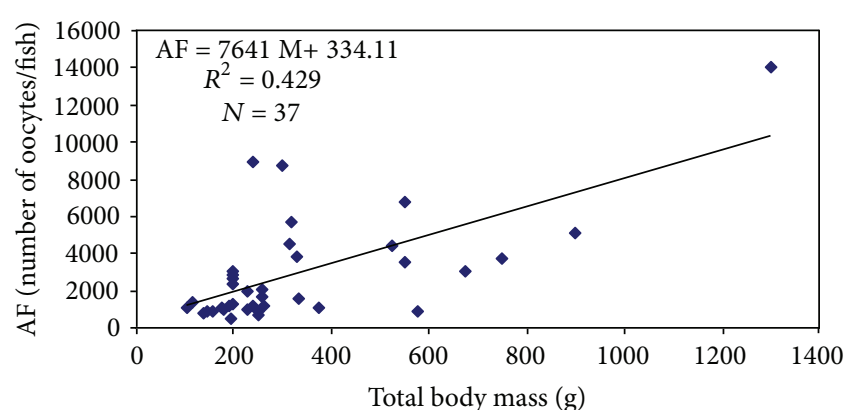

(b)

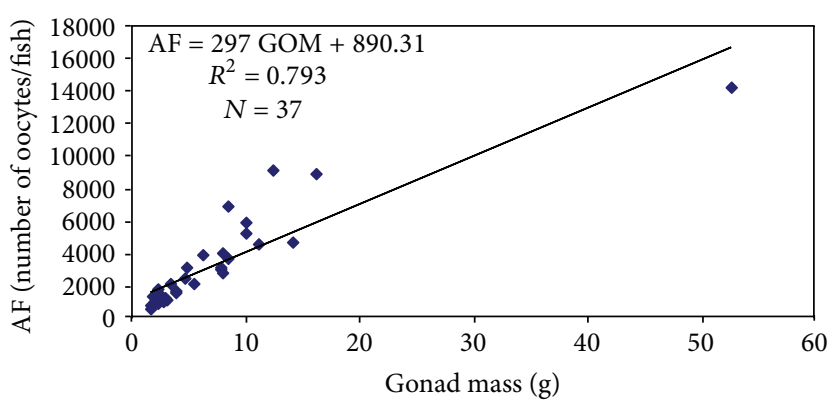

(c)

Figure 5: (a) Fecundity/total length, (b) total mass, and (c) gonad mass relationships of female Labeobarbus batesii. $N=$ number of females, $R^{2}=$ coefficient of determination, $\mathrm{AF}=$ absolute fecundity, TL = total length, $M=$ total body mass, and GOM = gonad mass.

observed characterise a fractional multiple spawning. Thus $L$. batesii has a group-synchronous oogenesis. Fecundity varies within years, months, and captures zones and is correlated with gonad mass. These features make L. batesii a suitable candidate for aquaculture.

\section{Acknowledgments}

The authors are grateful to the fishermen who helped in collecting the data and to the anonymous referees for their constructive review of this paper.

\section{References}

[1] FAO, "Statistics and information service of the fisheries and aquaculture department," in FAO Yearbook, Fisheries and Aquaculture Statistics, Rome, Italy, 2010.

[2] P. Fontaine, M. Legendre, M. Vandeputte, and A. Fostier, "Domestication de nouvelles espèces et développement durable de la pisciculture," Cahiers Agricultures, vol. 18, no. 2-3, pp. 119124, 2009.

[3] J. Lazard and C. Levêque, "Introduction et transferts d'espèces de poissons d'eau douce," Cahiers Agricultures, vol. 18, no. 2-3, pp. 157-163, 2009.

[4] O. Mikolasek, B. Barlet, E. Chia, V. Pouomogne, and E. T. M. Tomedi, "Développement de la petite pisciculture marchande au Cameroun: la recherche-action en partenariat," Cahiers Agricultures, vol. 18, no. 2-3, pp. 157-163, 2009.

[5] Anonymous, CLOFFA: Catalogue des poissons d'eau douce d'Afrique, Edited by J. Daget, J. P. Gosse; D. F. E Thys
Van den Audenaerde, ISNB, ORSTOM, MRAC. Collection/Coordonateurs, 1984.

[6] E. Montchowui, P. Laleye, J. C. Philippart, and P. Poncin, "Reproductive behaviour in captive African Carp, Labeo parvus Boulenger, 1902 (Piscies: Cyprinidae)," Journal of Fisheries International, vol. 6, no. 1, pp. 6-12, 2011.

[7] E. Montchowui, A. C. Bonou, P. Lalèye, and J. C. Philippart, "Successful artificial reproduction of the African carp: Labeo parvus Boulenger, (Pisces : Cyprinidae)," International Journal of Fisheres and Aquaculture, vol. 3, no. 3, pp. 35-40, 1902.

[8] E. Montchowui, P. Lalèye, E. N’tcha, J. C. Philippart, and P. Poncin, "Larval rearing of African carp, Labeo parvus Boulenger, 1902 (Pisces : Cyprinidae), using live food and artificial diet under controlled conditions," Aquaculture Research, vol. 43, no. 8, pp. 1243-1250, 2012.

[9] J. F. Guégan, D. Paugy, and C. Lévêque, "Létude des Barbuss dans le cadre d'un programme PICADOR: programme international sur les Cyprinidae Africains- Distribution et Origine," Cahiers d'Ethologie, vol. 13, no. 2, pp. 83-184, 1993.

[10] J. Lazard, "Introduction/Domestication d'espèces de poissons: Quelques éléments de réflexion. Unité propre de Recherche 'Aquaculture et gestion des ressources aquatiques,' Département emvt. CIRAD. Avenue Agropolis, TA 30/01,34398 Montpellier Cedex 5, Montpellier, France, 2006.

[11] Anonymous, Union Internationale pour la Conservation de la Nature (UICN). Wetlands, water and the law. Using law to advance wetland conservation and wise use. Clare Shine and Cyrille de Klemm. IUCN Evironmental policy and law, Paper no. 38, 2003, http://www.fao.org/docrep/009/a0113e/A0113Eo3.

[12] M. L. J. Stiassny, G. G. Teugels, and C. D. Hopkins, "Poissons d'eaux douces et saumâtres de la basse Guinée, Ouest de 
l'Afrique Centrale," in Faune et Flore Tropicales, Paris, vol. 1, p. 805, MRAC, Tervuren, Belgium, IRD edition, 2007.

[13] V. Pouomogne, "Capture-based aquaculture of Clarias catfish: case study of the Santchou fishers in western Cameroon," in Capture-Bsed Aquaculture. Global Overview, A. Lovatelli and P. F. Holthus, Eds., FAO Fisheries Technical Paper no. 508, pp. $93-$ 108, FAO, Rome, Italy, 2008.

[14] U. Ikpi and B. I. Okey, "Estimation of dietary composition and fecundity of African carp, Labeo coubie, Cross River, Nigeria," Journal of Applied Sciences and Environmental Management, vol. 14, no. 4, pp. 19-24, 2010.

[15] T. C. Tiogué, M. T. E. Tomedi, D. Nguenga, and J. Tchoumboué, "Caractéristiques de morphologie générale et de croissance du Cyprinidae africain Labeobarbus batesii dans la plaine inondable des Mbô, Cameroun," International Journal of Biological Sciences, vol. 4, no. 6, pp. 1988-2000, 2010.

[16] V. R. Suresh, B. K. Biswas, G. K. Vinci, K. Mitra, and A. Mukherjee, "Biology and fishery of barred spiny eel, Macrognathus pancalus Hamilton," Acta Ichthyologica et Piscatoria, vol. 36, no. 1, pp. 31-37, 2006.

[17] M. E. Allison, F. D. Sikoki, and I. F. Vincent-Abu, "Fecundity, sex-ratio, maturity stages, size at first maturity, breeding and spawning, of parailla pellucida (Boulenger, 1901) in the lowe Nun River, Niger Delta, Nigeria," Caderno de Pesquisa Srie Biologia, vol. 20, no. 2, pp. 31-47, 2008.

[18] S. B. Ekanem, "Some reproductive aspects of Chrysichthys nigrodigitatus (Lacepede) from Cross River Nigeria," Naga, the ICLARM quarterly, vol. 23, no. 2, pp. 24-27, 2000.

[19] M. Abedi, A. H. Shiva, H. Mohammadi, and R. Malekpour, "Reproductive biology and age determination of Garra rufa Heckel, 1843 (Actinopterygii: Cyprinidae) in central Iran," Turkish Journal of Zoology, vol. 35, no. 3, pp. 317-323, 2011.

[20] Z. A. Muchlisin, M. Musman, and M. N. S. Azizah, "Spawning seasons of Rasbora tawarensis (Pisces: Cyprinidae) in Lake Laut Tawar, Aceh Province, Indonesia," Reproductive Biology and Endocrinology, vol. 8, article 49, 2010.

[21] "Comportements et stratégies de reproduction chez les poissons," http://www.e-ocean.fr/index.php?option=com_content \&task=view\&id=21\&Itemid $=44$.

[22] E. Montchowui, P. Lalèyè, P. Poncin, and J. C. Philippart, "Reproductive strategy of Labeo senegalensis valenciennes 1842 (Teleostei: Cyprinidae) in the Ouémé basin, Benin," African Journal of Aquatic Science, vol. 35, no. 1, pp. 81-85, 2010.

[23] E. Montchowui, M. Ovidio, P. Laleye, J. C. Philippart, and P. Poncin, "Stratégies de reproduction et structure des populations chez Labeo parvus Boulenger, 1902 (Cypriniformes: Cyprinidae) dans le basin du fleuve Ouémé au Bénin," Annales des Sciences Agronomiques, vol. 15, no. 2, pp. 153-171, 2011.

[24] S. Bouhbouh, Bio-écologie de Barbus Callensis (Valencienne 1842) and Barbus fritschi (Günther 1874) au niveau du réservoir Allal El Fassi (Maroc) [Ph.D. thesis], Université SIDI Mohamed Ben Abdallah, Faculté des Sciences Dhar El Mehrazfes, 2002.

[25] M. Dorostghoal, R. Peyghan, F. Papan, and L. Khalili, "Macroscopic and microscopic studies of annual ovarian maturation cycle of Shirbot Barbus grypus in Karoon river of Iran," Iranian Journal of Veterinary Research, vol. 10, no. 2, pp. 172-179, 2009.

[26] V. L. De Vlaming, "Oocytes development patterns and hormonal involvements among Teleosts," in Control Process in Fish Physiology, J. C. Ranchin, T. J. Petcher, and R. Duggan, Eds., pp. 176-199, London Croom Helm, 1983.

[27] A. S. Oymak, N. Dogan, and E. Uysal, "Age, growth and reproduction of the Shabut Barbus grypus (Cyprinidae) in
Atatürk dam lake (Euphrates river), Turkey,' Cybium, vol. 32, no. 2, pp. 145-152, 2008.

[28] E. Montchowui, P. Lalèye, J. C. Philippart, and P. Poncin, "Biologie de la reproduction de Labeo parvus Boulenger, 1902 (Cypriniformes: Cyprinidae) dans le bassin du fleuve de l'Ouémé au Bénin (Afrique de l'Ouest)," Cahiers d'Ethologie, vol. 22, no. 2, pp. 61-80, 2007.

[29] F. Abou-Seedo and S. Dadzie, "Reproductive cycle in the male and female grey mullet, Liza klunzingeri in the Kuwaiti waters of the Arabian Gulf," Cybium, vol. 28, no. 2, pp. 97-104, 2004.

[30] N. M. Inyang and H. M. G. Ezenwaji, "Size, length-weigt relationship, reproduction and trophic biology of Chrysichthys nigridigitatus and Chrysichthys auratus (Siluriformes: Bagridae) in a Natural West African Lake," Bio-Research, vol. 2, no. 1, pp. 47-58, 2004.

[31] K. Demska-Zakes and M. Dlugosz, "Fecundity of vendace from two lakes of Mazurian district," Rybna, vol. 31, pp. 37-50, 1995.

[32] S. Mutambue, "Biologie et écologie de Barbus holotaenia, boulenger, 1904, du bassin de la rivière luki (ZAÏRE)," Bulletin Francais de la Peche et de la Protection des Milieux Aquatiques, vol. 69, no. 340, pp. 25-41, 1996. 

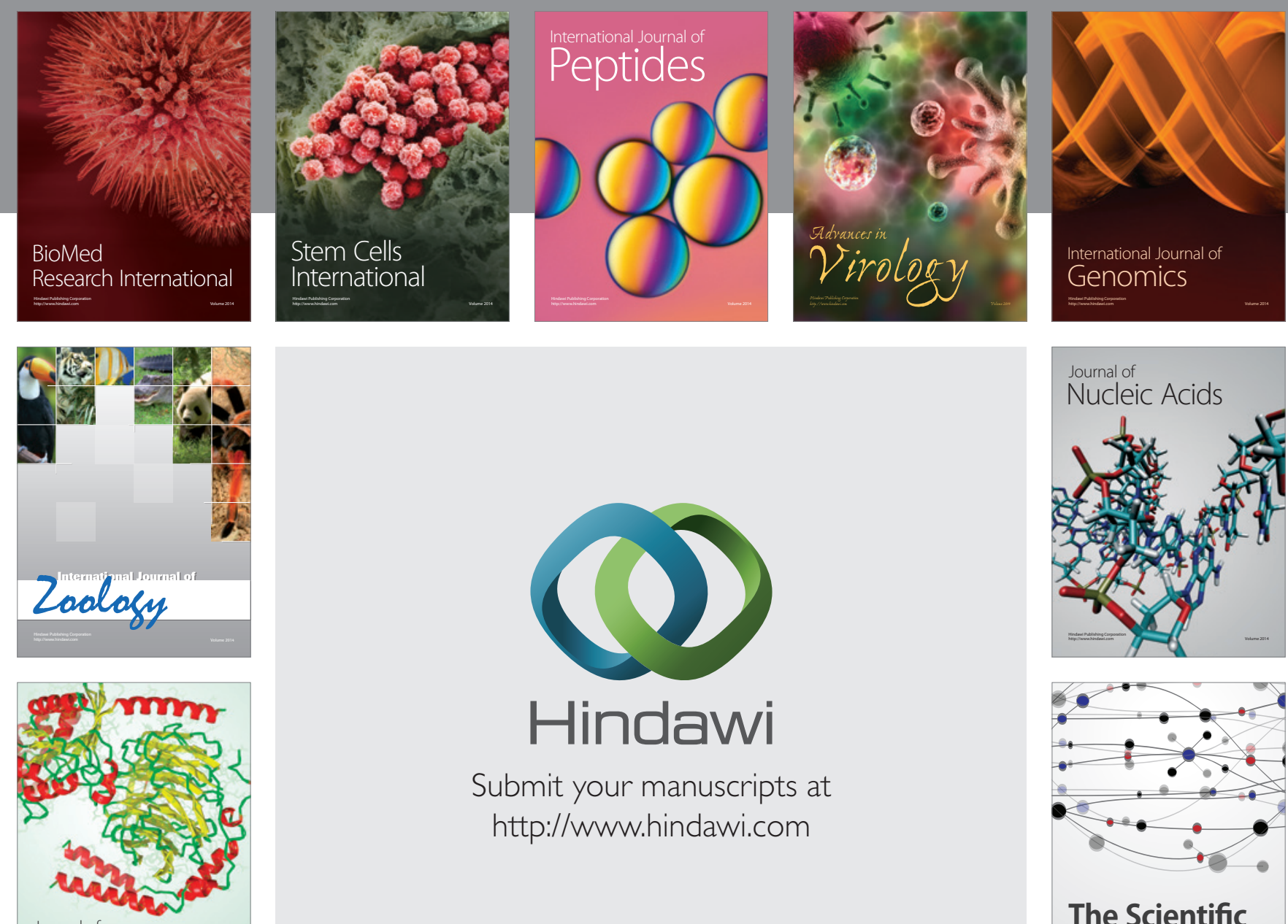

Submit your manuscripts at

http://www.hindawi.com

Journal of
Signal Transduction
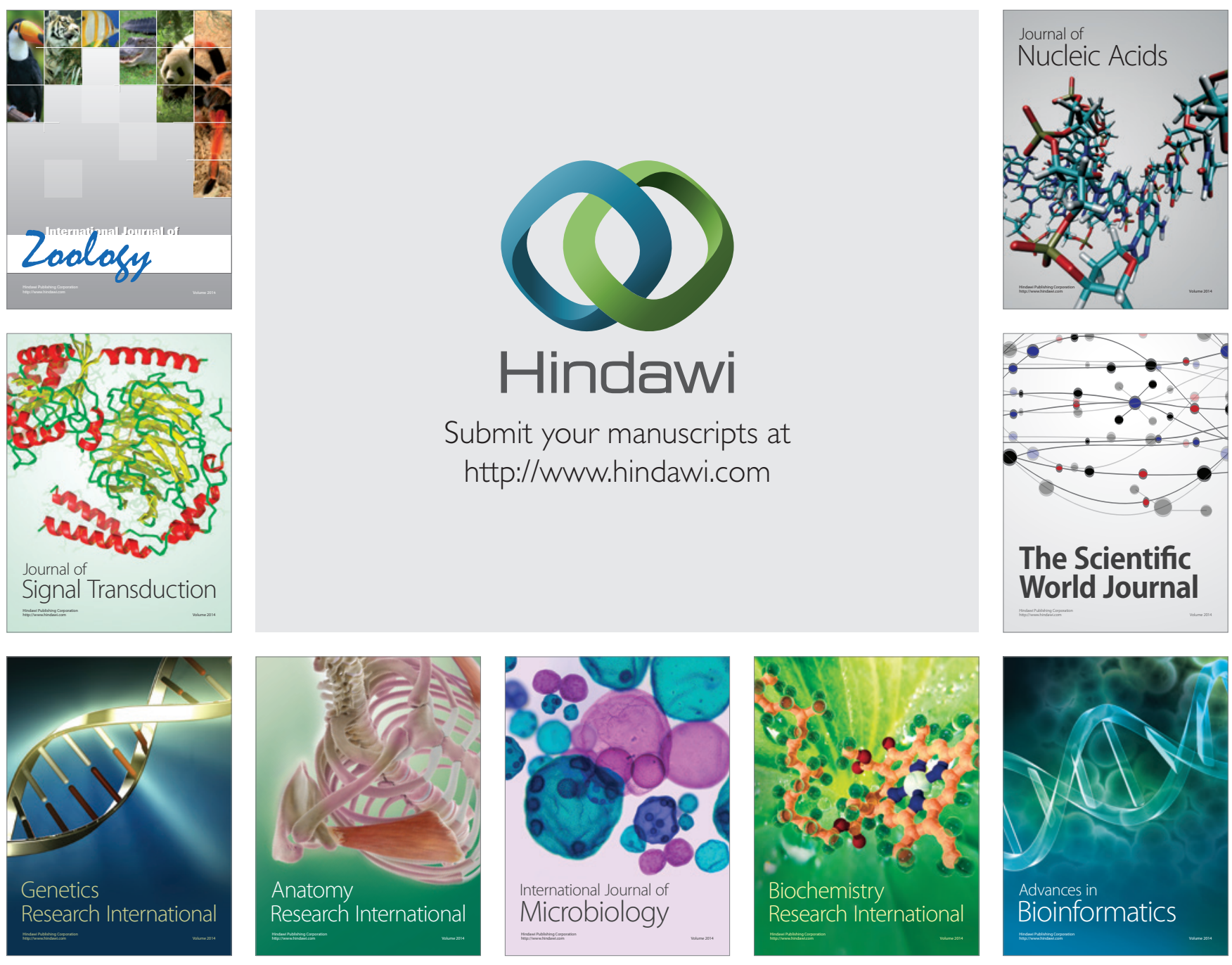

The Scientific World Journal
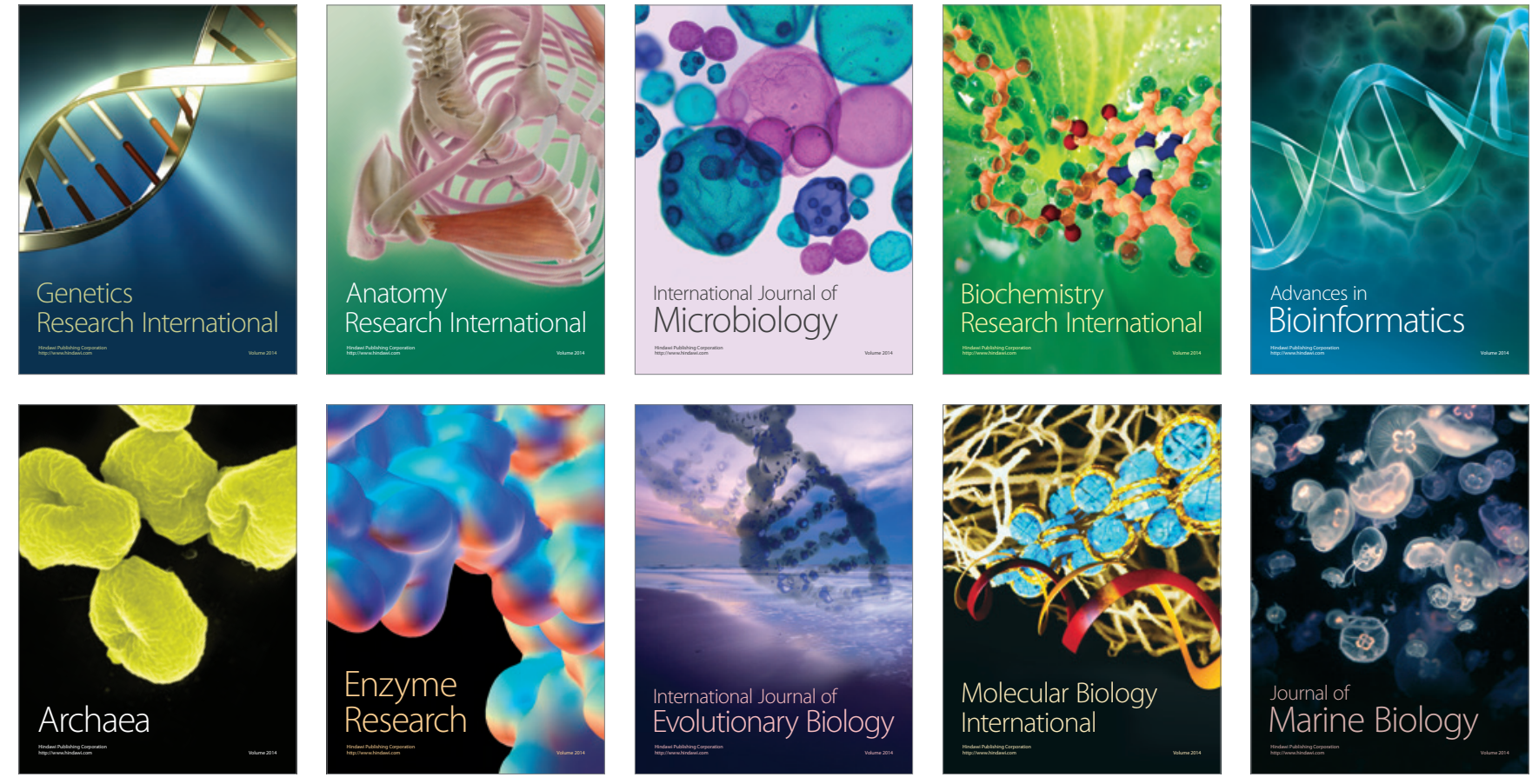